\title{
L-Arginine Abrogates Salt-sensitive Hypertension in Dahl/Rapp Rats
}

Pei Yan Chen and Paul W. Sanders

Nephrology Research and Training Center and Division of Nephrology, Department of Medicine, University of Alabama

at Birmingham, and Veterans Administration Medical Center, Birmingham, Alabama 35294

\begin{abstract}
This study examined the contribution of nitric oxide (NO) to the susceptibility or resistance to the hypertensive effects of high sodium chloride (8.0\% $\mathrm{NaCl})$ intake in young Dahl/Rapp salt-sensitive (SS/Jr) and salt-resistant (SR/Jr) rats. Using $N^{G}$-monomethyl-L-arginine (L-NMMA) as a probe for NO production in vivo, we found that increasing dietary sodium choride increased NO activity in salt-resistant rats, but not in salt-sensitive rats. Exogenous L-arginine, the substrate for NO synthesis, decreased blood pressure to normotensive levels in saltsensitive rats made hypertensive for 2 wk from $8.0 \% \mathrm{NaCl}$ chow. D-Arginine had no effect on blood pressure of these rats and L-arginine did not change blood pressure of salt-resistant rats. Intraperitoneal injections of $L$-arginine and its precursor, $\mathrm{L}$-citrulline, and oral L-arginine, but not $\mathrm{D}$-arginine, prevented the increase in blood pressure in salt-sensitive rats on the high salt chow over 2 wk of observation. In contrast, L-arginine did not alter the development of hypertension in spontaneously hypertensive rats. Mean urinary cGMP levels were higher in salt-sensitive rats on oral $L$-arginine than salt-sensitive rats on D-arginine. Infusion of L-NMMA acutely decreased, whereas intravenous $L$-arginine rapidly increased, urinary CGMP in both groups. L-Arginine and L-citrulline increased production of NO and prevented salt-sensitive hypertension in Dahl/Rapp rats. (J. Clin. Invest. 1991. 88:1559-1567.) Key words: endothelium-derived nitric oxide - endothelium-derived relaxing factor $\bullet N^{\mathbf{G}}$-monomethyl-L-arginine $\bullet$ nitric oxide synthase $\bullet$ urinary cyclic guanosine monophosphate $\bullet$ spontaneously hypertensive rats

\section{Introduction}

With the growing interest in the vascular endothelium as an endocrine organ that secretes vasodilatory and vasoconstrictor hormones $(1,2)$, recent studies have shown that endothelial cells secrete an important paracrine hormone, endothelium-

Portions of the material in this manuscript were presented at the 1990 meetings of the American Society of Nephrology and the Southern Section of the American Federation For Clinical Research and were published in abstract form (1990. J. Am. Soc. Nephrol. 1:439; and 1990. Clin. Res. 38:960A).

Address correspondence and reprint requests to Paul W. Sanders, M.D., Division of Nephrology/Department of Medicine, Sixth Floor, Zeigler Building, University of Alabama at Birmingham, Birmingham, AL 35294.

Received for publication 4 February 1991 and in revised form 10 June 1991.

J. Clin. Invest.

(c) The American Society for Clinical Investigation, Inc.

0021-9738/91/11/1559/09 \$2.00

Volume 88, November 1991, 1559-1567 derived nitric oxide (3). Nitric oxide (NO) ${ }^{1}$ has a short biologic half-life (4) and produces vasodilation by relaxation of smooth muscle cells of several arterial resistance vessels, including the renal vasculature (5), by increasing cGMP through activation of cytosolic guanylate cyclase $(4,6)$. The enzyme involved in the production of NO has been termed nitric oxide (NO) synthase and is stereoselective, utilizing L-arginine but not D-arginine as the substrate to produce nitric oxide $(4,7,8)$. NO synthase is competitively inhibited by $N^{\mathrm{G}}$-monomethyl-L-arginine (L-NMMA) $(4,7,9,10)$ or by other L-arginine molecules that have substitutions on the guanidino nitrogen atoms $(4$, 10). L-NMMA serves as a chemical probe of NO production in vivo and in vitro. Intravenous infusion of $L-N M M A$ produces rapid increases in blood pressure in humans $(11)$, rats $(5,12)$, rabbits (9), and guinea pigs (2); this increase in blood pressure is reversed with intravenous infusion of $L$-arginine. Thus, production of NO is an important determinant of resting arteriolar tone.

The pioneering work of Lewis K. Dahl produced from the Sprague-Dawley line two strains of rats that were either susceptible (S) or resistant $(\mathrm{R})$ to the hypertensive effects of a high salt $(8.0 \% \mathrm{NaCl})$ diet $(13,14)$. The Dahl $\mathrm{S}$ and $\mathrm{R}$ rats were inbred by John P. Rapp for 20 generations to yield two strains that were each homozygous at almost $100 \%$ of all genetic loci, thus fixing the characteristics of the strains (14). These Dahl/Rapp rats were either salt-sensitive (SS/Jr) or salt-resistant (SR/Jr). On an $8.0 \% \mathrm{NaCl}$ diet, the $\mathrm{SS} / \mathrm{Jr}$ rats rapidly and uniformly developed hypertension and died by 12 wk of age (14). Thus, the Dahl/ Rapp strains provide excellent models to investigate salt-sensitive hypertension and salt resistance.

We postulated that NO participates in the blood pressure response to changes in dietary sodium chloride intake. The purpose of this study was to examine the role of NO in the prevention and production of salt-sensitive hypertension in the SS/Jr and SR/Jr Dahl/Rapp rats.

\section{Methods}

\section{Protocols}

Series 1 (L-NMMA protocol). To examine the effect of dietary $\mathrm{NaCl}$ on the response to L-NMMA and L-arginine in vivo, male, 21-d-old, saltsensitive (SS/Jr) and salt-resistant (SR/Jr) Dahl/Rapp rats (Harlan Sprague-Dawley, Indianapolis, IN) were maintained on tap water and either $0.3 \% \mathrm{NaCl}$ or $8.0 \% \mathrm{NaCl}$ chow (both from Dyets, Inc., Bethlehem, PA) ad libitum for $2 \mathrm{wk}$. The diets were identical in composition except for the $\mathrm{NaCl}$ content. They were then anesthetized with ethyl, 1methylpropylthiobarbiturate (Inactin; BYK Gulden, Hamburg, FRG), $100 \mathrm{mg} / \mathrm{kg}$ body wt, i.p., and placed on a servo-controlled heated table.

\footnotetext{
1. Abbreviations used in this paper: GFR, inulin clearance; L-NMMA $N^{\mathrm{G}}$-monomethyl-L-arginine; MAP, mean arterial pressure; NO, nitric oxide; SR/Jr, Dahl/Rapp salt-resistant rat; SS/Jr, Dahl/Rapp salt-sensitive rat.
} 
Rectal temperature, which was maintained at $37^{\circ} \mathrm{C}$, was monitored with a telethermometer (Yellow Springs Instrument Co., Yellow Springs, $\mathrm{OH}$ ). Tracheostomy was performed with polyethylene PE-240 tubing, followed by catheterization of the right external jugular vein with PE-50 tubing for infusion of Ringer-bicarbonate with $8 \%$ polyfructosan (Inutest; Laevosan-Gesellschaft, Linz, Austria) at $1.2 \mathrm{ml} / 100$ $\mathrm{g}$ body $\mathrm{wt} / \mathrm{h}$ after a $1-\mathrm{ml}$ bolus; this infusion was maintained throughout the experiment. The left external jugular vein was then cannulated with PE-50 tubing for administration of drugs during the experiment. The right femoral artery was cannulated to record arterial blood pressure using a unigraph (model ICT-1H; Gilson Medical Electronics, Middleton, WI) and to sample blood. The bladder was catheterized through a suprapubic route for urine collection. After a 60-min equilibration period, arterial blood samples were collected for determination of hematocrit and plasma concentrations of inulin, sodium, and chloride. Two 30-min inulin clearances were obtained, then $N^{\mathrm{G}}$-monomethyl-L-arginine (L-NMMA) (Sigma Chemical Co., St. Louis, MO) was given intravenously as a bolus, $50 \mathrm{mg} / \mathrm{kg}$ body wt, followed by continuous infusion at $500 \mu \mathrm{g} / \mathrm{kg}$ body wt/min. This dose of L-NMMA was similar to that used by Tolins et al. (12). $10 \mathrm{~min}$ after infusion began a 30-min inulin clearance was performed. Mean arterial pressure (MAP) was recorded $30 \mathrm{~min}$ after the bolus was given. At the completion of the clearance, the infusion of L-NMMA was stopped and L-arginine (Sigma Chemical Co.), $300 \mathrm{mg} / \mathrm{kg}$ body wt, was given as an intravenous bolus. $10 \mathrm{~min}$ later another $30-\mathrm{min}$ inulin clearance was obtained and MAP $30 \mathrm{~min}$ after the intravenous injection of $\mathrm{L}$-arginine was recorded.

In a separate experiment, this same protocol was repeated using 21-d-old male Sprague-Dawley rats (Harlan Sprague-Dawley, Indianapolis, IN) on either 0.3 or $8.0 \% \mathrm{NaCl}$ chow for 2 wk. Results were compared between these two groups.

Series 2 (intravenous L-arginine treatment). To examine the effect of intravenous L-arginine and D-arginine on salt-sensitive hypertension, 21-d-old SS/Jr and SR/Jr rats were maintained on $8.0 \% \mathrm{NaCl}$ chow and tap water ad libitum for $2 \mathrm{wk}$. They were then anesthetized and surgically prepared as described above. After the 1-h equilibration period, a 30-min inulin clearance was obtained, then the rats received either D-arginine or L-arginine, $300 \mathrm{mg} / \mathrm{kg}$ body wt, as an intravenous bolus. The inulin clearance was repeated and MAP was determined 30 min after the bolus. At the completion of the inulin clearance, the rats were given another intravenous bolus of either $\mathrm{D}$-arginine or $\mathrm{L}$-arginine, $300 \mathrm{mg} / \mathrm{kg}$ body wt. A 30 -min inulin clearance was performed and the MAP was determined 30 min after the second bolus.

Series 3 (intraperitoneal L-arginine and L-citrulline treatment). To study the effect of i.p. L-arginine on the prevention of salt-sensitive hypertension, 21-d-old SS/Jr rats were maintained on $0.3 \% \mathrm{NaCl}$ chow and tap water ad libitum for $2 \mathrm{wk} .2 \mathrm{~d}$ before study, the rats were anesthetized with ether and the left femoral artery was catheterized with polyethylene tubing, which was tunneled subcutaneously to the nape of the neck. The animals were allowed to recover for $1 \mathrm{~d}$. The diet was then changed to $8.0 \% \mathrm{NaCl}$ chow and they were given daily i.p. injections of D-arginine, $250 \mathrm{mg} / \mathrm{kg}$ body wt, or L-arginine, 250,100 , or $25 \mathrm{mg} / \mathrm{kg}$ body wt. Approximately $2 \mathrm{~h}$ before each injection, MAP was recorded in these awake, unrestrained rats for $5 \mathrm{~d}$. The rats given the higher amounts of $\mathrm{L}$-arginine and D-arginine were continued for $2 \mathrm{wk}$. They were subsequently anesthetized with Inactin and prepared surgically as described in series 1 . After the 1-h equilibration period, a 30min inulin clearance was obtained, then L-NMMA was given intravenously as a bolus, $50 \mathrm{mg} / \mathrm{kg}$ body wt, followed by continuous infusion at $500 \mu \mathrm{g} / \mathrm{kg}$ body wt per min. $30 \mathrm{~min}$ after the bolus, MAP was recorded and the experiment was terminated.

In similar experiments, $\mathrm{L}$-citrulline, $250 \mathrm{mg} / \mathrm{kg}$ body wt, or vehicle was injected i.p. daily for $5 \mathrm{~d}$. After the sixth day, these rats were anesthetized and examined using the protocol described above.

In a separate study, 16 spontaneously hypertensive rats (SHR) (Charles River Breeding Laboratories, Inc., Wilmington, MA) 6 wk of age were placed on $8 \% \mathrm{NaCl}$ chow and tap water ad libitum for $2 \mathrm{wk}$. During this time, they received i.p. injections of L-arginine or D-argin- ine, $250 \mathrm{mg} / \mathrm{kg}$ body wt per day. Systolic blood pressures were determined using a tail cuff attached to a blood pressure analyzer (IITC, Inc., Woodland Hills, CA) twice weekly in these rats while in a conscious, prewarmed, and restrained state. At the end of the 2-wk period, the rats were anesthetized with ether and a catheter was inserted into the left femoral artery and tunneled subcutaneously to the nape of the neck. Two rats died inexplicably during the recovery period from the ether anesthesia. The rats were allowed to recover for $1 \mathrm{~d}$, then MAP was recorded in conscious and unrestrained rats. The rats were then anesthetized with Inactin, prepared surgically and the protocol described above was repeated. In addition, urine samples from each clearance period were collected in $0.1 \mathrm{mM}$ 3-isobutyl-1-methylxanthine (Sigma Chemical Co.) and immediately frozen and stored at $-20^{\circ} \mathrm{C}$. The samples were processed simultaneously for determination of CGMP.

Series 4 (oral L-arginine treatment). This protocol was similar to the one described in series $3.2 \mathrm{wk}$ after beginning the $0.3 \% \mathrm{NaCl}$ diet, the left femoral artery was catheterized for recording awake blood pressure as described above. The animals were allowed to recover for $1 \mathrm{~d}$, then the diet was then changed to $8.0 \% \mathrm{NaCl}$ chow and they were given either D-arginine or L-arginine, $1.25 \mathrm{~g}$ /liter, to drink ad libitum for 2 wk. MAP was recorded each morning in these awake, unrestrained rats. The rats were weighed daily and the amount of fluid intake recorded. After $2 \mathrm{wk}$, the rats were anesthetized with Inactin and prepared surgically as described in the series 1 . After the 1-h equilibration period, a 30-min inulin clearance was obtained, then L-NMMA was given intravenously as a bolus, $50 \mathrm{mg} / \mathrm{kg}$ body wt, followed by continuous infusion at $500 \mu \mathrm{g} / \mathrm{kg}$ body wt per min. $10 \mathrm{~min}$ after infusion began a 30-min inulin clearance was performed. MAP was recorded $30 \mathrm{~min}$ after the bolus was given. At the completion of the clearance, the infusion of L-NMMA was stopped and L-arginine, $300 \mathrm{mg} / \mathrm{kg}$ body wt, was given as an intravenous bolus. MAP was recorded $30 \mathrm{~min}$ after the intravenous injection of $L$-arginine and the experiment was terminated.

In these experiments, the urine samples from each period were collected in 0.1 mM 3-isobutyl-1-methylxanthine (Sigma Chemical Co.) and immediately frozen and stored at $-20^{\circ} \mathrm{C}$. The samples were processed simultaneously for determination of cGMP.

\section{Analytical techniques}

Plasma and urine sodium concentrations were determined with a flame photometer (model IL-943; Instrumentation Laboratories, Inc., Lexington, MA). Plasma and urine chloride concentrations were determined amperometrically (Buchler digital chloridometer; Buchler Instruments, Inc., Fort Lee, NJ). Concentration of inulin in plasma and urine was determined by the anthrone colorimetric method, which has been standardized in our laboratory (15). Clearance of inulin (GFR) was calculated from these values and was factored by body weight. Measurement of cGMP was accomplished with a cGMP ELISA kit (Cayman Chemical Co., Ann Arbor, MI).

\section{Statistical analysis}

All values were expressed as mean \pm SEM. Comparisons between two groups and within a group were analyzed for statistical significance by unpaired and paired $t$ tests, respectively. Comparisons among more than two groups were analyzed for statistical significance by analysis of variance and the Scheffe F-test using statistical software (Statview $512+$; Abacus Concepts, Inc., Berkeley, CA). Significance was set at the $5 \%$ level.

\section{Results}

Series 1 (L-NMMA protocol) (Table I). At the time of study, mean age and body weight of the four groups were $37 \pm 0 \mathrm{~d}$ and $162 \pm 4 \mathrm{~g}$ and did not differ among the four groups (data not shown). After surgical preparation and the equilibration period, baseline urinary excretion rates of sodium (35 \pm 12 vs. $22 \pm 4 \mathrm{nEq} / \mathrm{min}$ per $100 \mathrm{~g}$ body $\mathrm{wt})$ and chloride (66 $99 \mathrm{vs}$. 
Table I. Effects of L-NMMA and L-Arginine on MAP and GFR in Anesthetized, 37-d-old SS/Jr and SR/Jr Rats and Sprague-Dawley Rats after $14 \mathrm{~d}$ on the Indicated $\mathrm{NaCl}$ Diet

\begin{tabular}{|c|c|c|c|c|c|c|c|c|c|}
\hline \multirow[b]{2}{*}{ Group } & \multirow[b]{2}{*}{ Dietary $\mathrm{NaCl}$} & \multirow[b]{2}{*}{$n$} & \multicolumn{2}{|c|}{ Baseline data } & \multicolumn{3}{|c|}{ L-NMMA } & \multicolumn{2}{|r|}{ L-Arginine } \\
\hline & & & MAP & GFR & MAP & $\begin{array}{l}\% \text { change } \\
\text { in MAP }\end{array}$ & GFR & MAP & GFR \\
\hline & $\%$ & & $m m H g$ & $\mu \mathrm{l} / \mathrm{min} / 100 \mathrm{~g}$ body $w t$ & $m m H g$ & $\%$ & $\mu \mathrm{l} / \mathrm{min} / 100 \mathrm{~g}$ body $w t$ & $m m H g$ & $\mu l / m i n / 100 \mathrm{~g}$ body $w t$ \\
\hline $\mathrm{SS} / \mathrm{Jr}$ & 0.3 & 6 & $106 \pm 3$ & $1044 \pm 46$ & $130 \pm 5^{8}$ & $+22.2 \pm 1.5$ & $1059 \pm 50$ & $107 \pm 4$ & $914 \pm 65$ \\
\hline $\mathrm{SR} / \mathrm{Jr}$ & 0.3 & 8 & $111 \pm 2$ & $1034 \pm 88$ & $134 \pm 2^{\S}$ & $+20.5 \pm 1.3$ & $1050 \pm 106$ & $108 \pm 3$ & $1065 \pm 30$ \\
\hline $\mathrm{SS} / \mathrm{Jr}$ & 8.0 & 6 & $138 \pm 1^{*}$ & $1089 \pm 48$ & $168 \pm 1 *$ & $+21.4 \pm 0.7$ & $1037 \pm 41$ & $125 \pm 2 * 5$ & $990 \pm 106$ \\
\hline $\mathrm{SR} / \mathrm{Jr}$ & 8.0 & 6 & $114 \pm 2$ & $1330 \pm 37^{*}$ & $149 \pm 2 \neq \S$ & $+31.1 \pm 0.7^{*}$ & $834 \pm 128^{5}$ & $113 \pm 3$ & $1084 \pm 80$ \\
\hline$P$ & & & 0.0001 & 0.008 & 0.0001 & 0.0001 & & 0.001 & \\
\hline SD & 0.3 & 5 & $114 \pm 3$ & $521 \pm 69$ & $141 \pm 4^{8}$ & $+23.9 \pm 1.0$ & $1115 \pm 294$ & $111 \pm 4$ & $933 \pm 221$ \\
\hline SD & 8.0 & 5 & $113 \pm 2$ & $670 \pm 68$ & $157 \pm 5^{5}$ & $+38.9 \pm 4.0$ & $1115 \pm 143^{8}$ & $118 \pm 4$ & $958 \pm 162$ \\
\hline$P$ & & & & & 0.03 & 0.006 & & & \\
\hline
\end{tabular}

$\mathrm{SD}$, Sprague-Dawley. ${ }^{*}$ Statistically different value among the four groups of Dahl/Rapp rats. ${ }^{\ddagger} P=0.0001$ vs. SR/Jr group on $0.3 \% \mathrm{NaCl}$ diet. ${ }^{8} P$ $<0.05$ vs. the baseline values in the same group.

$86 \pm 13 \mathrm{nEq} / \mathrm{min}$ per $100 \mathrm{~g}$ body wt) did not differ between $\mathrm{SR} / \mathrm{Jr}$ and $\mathrm{SS} / \mathrm{Jr}$ rats on the low-salt chow. The SR/Jr and SS/Jr groups on the high-salt chow had baseline urinary excretion rates of sodium $(498 \pm 152$ vs. $942 \pm 179 \mathrm{nEq} / \mathrm{min}$ per $100 \mathrm{~g}$ body wt) and chloride ( $759 \pm 187$ vs. $1,303 \pm 225 \mathrm{nEq} / \mathrm{min}$ per $100 \mathrm{~g}$ body $\mathrm{wt})$ that did not differ and were higher $(P=0.0004)$ than the two groups on the low-salt chow. SR/Jr and SS/Jr rats on the $0.3 \% \mathrm{NaCl}$ diet and $\mathrm{SR} / \mathrm{Jr}$ rats on $8.0 \% \mathrm{NaCl}$ chow had similar MAPs, whereas MAP of SS/Jr rats on the $8.0 \% \mathrm{NaCl}$ diet was higher $(P=0.0001)$ than the other three groups (Table I). GFR was higher $(P=0.008)$ in the $S R / J r$ rats on the $8.0 \%$ $\mathrm{NaCl}$ diet, compared with the other three groups. L-NMMA infusion produced a rapid (within $2 \mathrm{~min}$ ) and sustained increase $(P<0.05)$ in MAP in all four groups; but compared with the increase in MAP in the SR/Jr rats on the low-salt diet, MAP increased to a greater degree $(P=0.0001)$ in the $S R / J r$ group on the high-salt diet. The $31.1 \pm 0.7 \%$ increase in MAP in the SR/Jr group on the high-salt diet during L-NMMA infusion was greater $(P=0.0001)$ than the other three groups (Table I). Infusion of L-NMMA did not change GFR of the SR/Jr rats on the low-salt chow, but decreased GFR $37.6 \pm 8.6 \%$ in SR/Jr rats on the high-salt chow. L-NMMA infusion did not change GFR and increased MAP in proportional increments $(22.2 \pm 1.5 \%$ vs. $21.4 \pm 0.7 \%$ ) in $\mathrm{SS} / \mathrm{Jr}$ rats on the two diets. With $\mathrm{L}$-arginine infusion, final MAP was higher $(P=0.001)$ in the SS/Jr rats on the $8.0 \% \mathrm{NaCl}$ chow than the other three groups, but was lower $(P<0.05)$ than the baseline MAP of this high-salt group.

Mean body weights of the low-salt and the high-salt groups of Sprague-Dawley rats at the time of study were $151 \pm 4$ and $144 \pm 3 \mathrm{~g}$. After surgical preparation and the equilibration period, baseline urinary excretion rates of sodium (38 \pm 5 vs. $329 \pm 124 \mathrm{nEq} / \mathrm{min}$ per $100 \mathrm{~g}$ body $\mathrm{wt}$ ) and chloride ( $54 \pm 4 \mathrm{vs}$. $400 \pm 169 \mathrm{nEq} / \mathrm{min}$ per $100 \mathrm{~g}$ body $\mathrm{wt}$ ) reflected differences in the dietary sodium chloride intake of the low- and high-salt groups. Baseline MAP did not differ between the two groups (Table I). Hypertension did not develop in any of the five rats after 2 wk on the high-salt chow. With infusion of L-NMMA, MAP rose further $(P=0.03)$ in the rats on the high-salt chow. Mean GFR at baseline did not differ between these groups and both increased during infusion of L-NMMA to comparable lev-

Table II. Effects of L-Arginine and D-Arginine on MAP and GFR in Anesthetized, 38-d-old SS/Jr and SR/Jr Rats after $14 d$ on the 8.0\% NaCl Diet

\begin{tabular}{|c|c|c|c|c|c|c|c|c|c|}
\hline \multirow[b]{3}{*}{ Group } & \multirow[b]{3}{*}{$n$} & \multirow{2}{*}{\multicolumn{2}{|c|}{ Baseline }} & \multicolumn{6}{|c|}{ Arginine dose } \\
\hline & & & & \multicolumn{3}{|c|}{$300 \mathrm{mg} / \mathrm{kg}$} & \multicolumn{3}{|c|}{$600 \mathrm{mg} / \mathrm{kg}$} \\
\hline & & MAP & GFR & MAP & $\begin{array}{l}\% \text { change } \\
\text { in MAP }\end{array}$ & GFR & MAP & $\begin{array}{l}\% \text { change } \\
\text { in MAP }\end{array}$ & GFR \\
\hline & & $m m H g$ & $\mu \mathrm{l} / \mathrm{min} / 100 \mathrm{~g}$ body $\mathrm{wt}$ & $m m H g$ & $\%$ & $\mu \mathrm{l} / \mathrm{min} / 100 \mathrm{~g}$ body $w t$ & $m m H g$ & $\%$ & $\mu l / m i n / 100 \mathrm{~g}$ body $w t$ \\
\hline \multicolumn{10}{|l|}{ D-Arginine } \\
\hline $\begin{array}{c}\text { SS/Jr } \\
\text { L-Arginine }\end{array}$ & 6 & $140 \pm 3$ & $1007 \pm 34$ & $146 \pm 5^{*}$ & $+0.6 \pm 0.6$ & $1016 \pm 44$ & $142 \pm 5^{*}$ & $-2.1 \pm 1.7$ & $1031 \pm 55$ \\
\hline $\mathrm{SS} / \mathrm{Jr}$ & 6 & $145 \pm 4$ & $1035 \pm 43$ & $117 \pm 6^{\ddagger}$ & $-16.6 \pm 2.9^{*}$ & $996 \pm 48$ & $110 \pm 4^{\ddagger}$ & $-21.1 \pm 2.8^{*}$ & $902 \pm 73^{\ddagger}$ \\
\hline $\begin{array}{l}\mathrm{SR} / \mathrm{Jr} \\
P\end{array}$ & 7 & $118 \pm 4^{*}$ & $1086 \pm 42$ & $117 \pm 4$ & $-0.2 \pm 0.7$ & $1111 \pm 30$ & $114 \pm 4$ & $-2.6 \pm 0.8$ & $1110 \pm 34$ \\
\hline$P$ & & 0.0002 & & 0.0008 & 0.0001 & & 0.0001 & 0.0001 & \\
\hline
\end{tabular}

* Statistically different value among the three groups. ${ }^{\ddagger} P<0.05$ compared with the baseline values. 


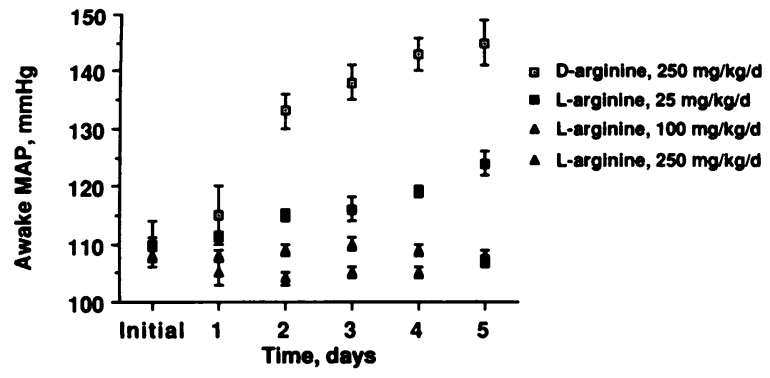

Figure 1. Effects of daily i.p. injections of D-arginine, $250 \mathrm{mg} / \mathrm{kg}$ body wt, and L-arginine, 250,100 , and $25 \mathrm{mg} / \mathrm{kg}$ body wt, on MAP of awake unrestrained SS/Jr rats on the high-salt diet. At baseline, MAP of the four groups of rats did not differ. In the rats given D-arginine, a rapid and sustained increase in MAP from $110 \pm 4$ to $145 \pm 4 \mathrm{mmHg}$ occurred over the $5 \mathrm{~d}$ of observation. This increase in blood pressure became significant $(P=0.0001)$ from the other three groups by the second day of observation. MAP remained unchanged in the groups receiving $\mathrm{L}$-arginine, $250 \mathrm{mg} / \mathrm{kg}$ body wt per $\mathrm{d}(108 \pm 1$ to $108 \pm 1$ $\mathrm{mmHg})$, and $\mathrm{L}$-arginine, $100 \mathrm{mg} / \mathrm{kg}$ body wt per $\mathrm{d}(108 \pm 1$ to $107 \pm 1$ $\mathrm{mmHg}$ ), and did not differ. An intermediate response was seen in the group given L-arginine, $25 \mathrm{mg} / \mathrm{kg}$ body wt per d, with MAP increasing from $110 \pm 1$ to $124 \pm 2 \mathrm{mmHg}$ by the fifth day. By day four, the blood pressure response of this group receiving the lowest dose of $\mathrm{L}$-arginine differed $(P=0.0001)$ from the other two groups given the higher doses of $\mathrm{L}$-arginine.

els (Table I). Because of the variability of the response, however, the increase in GFR of the low-salt group did not reach statistical significance $(P=0.08)$.

Series 2 (intravenous L-arginine treatment) (Table II). These rats had been fed the $8.0 \% \mathrm{NaCl}$ chow for $14 \mathrm{~d}$ before study. Mean age of the rats at the time of study was $38 \pm 0 \mathrm{~d}$ and was not different among the three groups (data not shown). After surgical preparation and equilibration, baseline urinary excretion rates of sodium (in $\mathrm{nEq} / \mathrm{min}$ per $100 \mathrm{~g}$ body $\mathrm{wt}$ ) were $776 \pm 103$ (SS/Jr-D-arginine), 1,468 \pm 458 (SS/Jr-L-arginine), and $789 \pm 173$ (SR/Jr-L-arginine) and did not differ among the three groups. Baseline urinary excretion rates of chloride (in $\mathrm{nEq} / \mathrm{min}$ per $100 \mathrm{~g}$ body $\mathrm{wt}$ ) were $1,363 \pm 256$ (SS/Jr-D-arginine), $1,869 \pm 516$ (SS/Jr-L-arginine), and 1,169 \pm 249 (SR/Jr-Larginine) and did not differ among the three groups. As expected, on the high-salt diet MAP was higher $(P=0.0002)$ in the SS/Jr rats than the SR/Jr rats; average GFRs were similar in all three groups (Table II). Infusion of D-arginine or L-arginine produced rapid, transient decreases in MAP in both SS/Jr and $\mathrm{SR} / \mathrm{Jr}$ rats; within $5 \mathrm{~min}$, MAP returned to baseline in the $\mathrm{SR} / \mathrm{Jr}$ rats treated with $\mathrm{L}$-arginine and in $\mathrm{SS} / \mathrm{Jr}$ rats treated with $\mathrm{D}$-arginine. After $30 \mathrm{~min}$, the L-arginine infusion produced no net change in MAP in the SR/Jr rats, but decreased MAP $21.1 \pm 2.8 \%$ in the SS/Jr rats; thus, MAP of SS/Jr rats was lowered to values comparable to the $S R / J r$ strain. The D-arginine infusion did not change MAP of the SS/Jr rats. After the second injection of L-arginine, GFR fell slightly in the SS/Jr rats from $1,035 \pm 43$ to $902 \pm 73 \mu \mathrm{l} / \mathrm{min}$ per $100 \mathrm{~g}$ body wt $(P<0.05)$.

Series 3 (intraperitoneal L-arginine and $L$-citrulline treatment). Daily i.p. injections of L-arginine, 100 and $250 \mathrm{mg} / \mathrm{kg}$ body wt per d, prevented the rise in awake MAP in SS/Jr rats on the $8.0 \% \mathrm{NaCl}$ diet, but i.p. injections of $\mathrm{D}$-arginine had no effect on the increase in MAP, which developed rapidly and was sustained over the $5 \mathrm{~d}$ of observation (Fig. 1). L-Arginine, $25 \mathrm{mg} / \mathrm{kg}$ body wt per d, i.p., partially prevented the increase in MAP in these rats (Fig. 1). At 2 wk, mean body weights of the rats receiving $D$-arginine and L-arginine, $250 \mathrm{mg} / \mathrm{kg}$ body wt per d, were comparable (Table III). MAP under anesthesia remained elevated $(152 \pm 4 \mathrm{mmHg})$ in the $\mathrm{D}$-arginine group, but was $118 \pm 2 \mathrm{mmHg}$ in the L-arginine group. GFRs did not differ between these groups. With L-NMMA infusion, MAP rose to similar levels in both groups, but the percent increase $(44.7 \pm 3.2 \%)$ in MAP was greater $(P=0.0004)$ in the L-arginine group (Table III). The $18.0 \pm 1.3 \%$ increase in MAP in the D-arginine group from L-NMMA infusion did not differ $(P$ $=0.1445$ ) from the responses that occurred in the SS/Jr rats on either diet and the SR/Jr rats on the low-salt diet in series 1 (Table I).

Daily i.p. injections of L-citrulline, $250 \mathrm{mg} / \mathrm{kg}$ body wt, prevented the increase in blood pressure in SS/Jr rats on the high-salt chow (Fig. 2). When studied on the sixth day of treatment, mean body weights and GFRs did not differ (Table IV). MAP under anesthesia remained elevated $(148 \pm 2 \mathrm{mmHg})$ in the vehicle-treated rats, but was $106 \pm 1 \mathrm{mmHg}$ in the L-citrulline group. The percent increase in MAP in response to infusion of L-NMMA (Table IV) was comparable to that seen in the L-arginine-treated animals (Tables I and III).

In the spontaneously hypertensive rats treated i.p. with Larginine or D-arginine, mean body weights (Table V) did not differ. Initial mean systolic blood pressures (146 \pm 7 vs. $148 \pm 6$ $\mathrm{mmHg} ; P=0.8777$ ) also did not differ. Comparable increases in mean systolic blood pressures in the two groups treated with L-arginine or D-arginine were found at the end of the first $(164 \pm 5$ vs. $155 \pm 7 \mathrm{mmHg} ; P=0.2546)$ and second weeks $(186 \pm 2$ vs. $189 \pm 2 \mathrm{mmHg} ; P=0.2106)$. Awake MAP (165 \pm 4 vs. $163 \pm 5 \mathrm{mmHg} ; P=0.7804$ ) of the two groups at the end of the 2-wk period did not differ. Anesthetized MAP and GFR and the responses to L-NMMA and L-arginine were comparable (Table V). Urinary [cGMP] at baseline $(25.7 \pm 4.6$ vs. $32.0 \pm 5.7 \mathrm{pmol} / \mathrm{ml} \mathrm{GFR}$ per $100 \mathrm{~g}$ body wt; $P=0.4043$ ), during infusion of L-NMMA $(43.9 \pm 14.6$ vs. $45.2 \pm 11.4 \mathrm{pmol} / \mathrm{ml} \mathrm{GFR}$

Table III. Data from SS/Jr Rats after 2 wk on 8\% NaCl Chow and Daily i.p. Injections of Either L-Arginine or D-Arginine

\begin{tabular}{|c|c|c|c|c|c|c|}
\hline \multirow[b]{3}{*}{ Group } & \multirow[b]{3}{*}{$n$} & \multirow{3}{*}{$\begin{array}{c}\text { Body } \\
\text { wt }\end{array}$} & \multirow{2}{*}{\multicolumn{2}{|c|}{ Baseline data }} & \multicolumn{2}{|c|}{ L-NMMA } \\
\hline & & & & & \multirow[b]{2}{*}{ MAP } & \multirow{2}{*}{$\begin{array}{c}\% \text { increase } \\
\text { in MAP }\end{array}$} \\
\hline & & & MAP & GFR & & \\
\hline & & $g$ & $m m H g$ & $\mu l / \min / 100 \mathrm{~g}$ body $w t$ & $m m H g$ & $\%$ \\
\hline L-Arginine & 7 & $221 \pm 7$ & $118 \pm 2$ & $993 \pm 54$ & $171 \pm 3$ & $44.7 \pm 3.2$ \\
\hline D-Arginine & 6 & $224 \pm 13$ & $152 \pm 4$ & $942 \pm 29$ & $179 \pm 5$ & $18.0 \pm 1.3$ \\
\hline$P$ & & & 0.0001 & & & 0.0001 \\
\hline
\end{tabular}




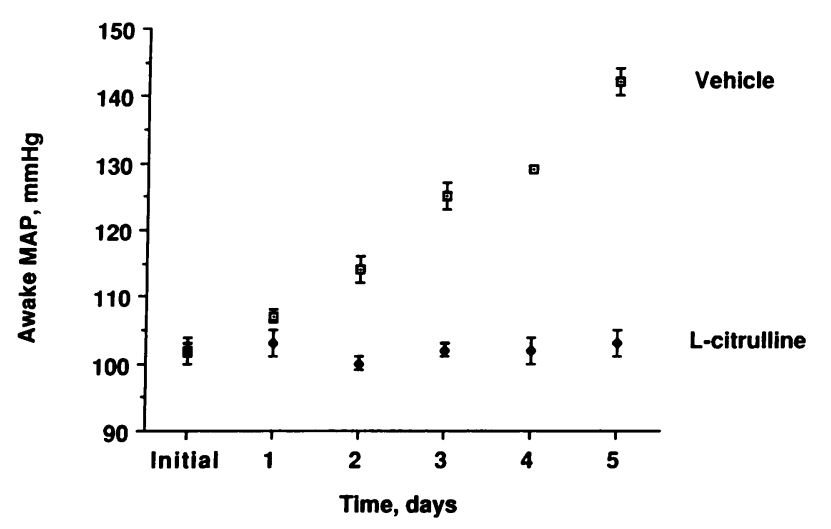

Figure 2. Effect of daily i.p. injections of L-citrulline, $250 \mathrm{mg} / \mathrm{kg}$ body wt, or vehicle on MAP of awake unrestrained SS/Jr rats on the highsalt diet. In the rats given vehicle, a rapid and sustained increase in MAP from $102 \pm 2$ to $142 \pm 2 \mathrm{mmHg}$ occurred over the $5 \mathrm{~d}$ of observation. Over the same interval, MAP remained unchanged $(102 \pm 1$ to $103 \pm 2 \mathrm{mmHg}$ ) in the L-citrulline group. Differences between the blood pressures of the two groups became significant $(P=0.0001)$ by the second day of treatment.

per $100 \mathrm{~g}$ body wt; $P=0.9496)$, and after intravenous bolus of L-arginine $(25.1 \pm 6.7$ vs. $21.7 \pm 5.3 \mathrm{pmol} / \mathrm{ml}$ GFR per $100 \mathrm{~g}$ body wt; $P=0.7059$ ) did not differ between the two groups. Within each group, L-NMMA had a small effect on MAP (Table V) and no effect on urinary [cGMP]; L-arginine did not reduce MAP below baseline and did not change urinary [cGMP].

Series 4 (oral L-arginine treatment). SS/Jr rats on the D-arginine drink developed increases in MAP on the high-salt diet, whereas those rats given the $\mathrm{L}$-arginine drink remained normotensive (Fig. 3). One of the rats on D-arginine died $10 \mathrm{~d}$ into the study. At 2 wk, mean body weights (Table VI) and fluid intake $(84 \pm 4$ vs. $85 \pm 4 \mathrm{ml} / \mathrm{d})$ did not differ. Mean GFR and MAP were greater in the D-arginine group (Table VI). With infusion of L-NMMA, blood pressure increased in both groups. Again, the percent increase in MAP was greater $(P=0.0001)$ in the L-arginine group, whereas the $17.1 \pm 2.2 \%$ increase that occurred in the D-arginine group was similar to the increases seen in the $\mathrm{SS} / \mathrm{Jr}$ groups in series 1 (Table I). L-Arginine infusion rapidly corrected the blood pressure in the L-arginine group and lowered $(P<0.05)$ MAP $\sim 30 \mathrm{mmHg}$ below baseline MAP in the D-arginine treated rats (Table VI).

Mean baseline urinary cGMP concentration was higher $(P$ $=0.03)$ in the $\mathrm{L}$-arginine group than the $\mathrm{D}$-arginine group $(\mathrm{Ta}-$ ble VII). With infusion of L-NMMA, urinary cGMP rapidly decreased in both groups to comparable levels as blood pressure increased. With cessation of the L-NMMA infusion and the single intravenous bolus of L-arginine, urinary cGMP increased in both groups, and was higher $(P=0.03)$ in the L-arginine group.

\section{Discussion}

Since the original description of endothelium-derived relaxing factor by Furchgott and Zawadzki (16), several laboratories reported that this paracrine hormone was NO or a combination of NO and a labile nitroso precursor of NO $(1-4,8)$. NO, a gas that has a very short half-life, has been difficult to measure (4). Most assays for NO have not quantitated NO directly but instead used indirect means such as cGMP generation $(4,6,12$, 17), bioassay that examines changes in relaxation of aortic smooth muscle strips $(4,8,18)$, or the effects of inhibitors of NO production $(2,4,5,7,9,11,12,17)$. NO has been shown to be synthesized by endothelial cells in vivo and in culture from L-arginine, but not from D-arginine (1, 2, 4, 7-9); synthesis of NO was stereospecifically inhibited by $N^{\mathrm{G}}$-monomethyl-L-arginine (L-NMMA) $(1,2,4,7,9,17,18)$. Because L-NMMA had no direct constrictor or dilator effects on vascular smooth muscle, this drug increased blood pressure by abolishing endothelium-derived vasodilation through inhibition of NO production $(9,18)$. Our current studies utilized this information to demonstrate several new findings in blood pressure regulation in the Dahl/Rapp salt-sensitive (SS/Jr) and salt-resistant (SR/ $\mathrm{Jr}$ ) strains of rat. Using L-NMMA as a probe of NO activity, we showed that NO was present in SS/Jr, SR/Jr and Sprague-Dawley rats on the $0.3 \% \mathrm{NaCl}$ diet and was a determinant of resting arteriolar tone even on this low-salt diet (Table I). These data were consistent with previous reports demonstrating a basal release in resistance vessels of NO, which maintained baseline arteriolar tone and blood pressure in humans, rats, rabbits, and guinea pigs $(2,5,9,11,12)$. L-NMMA infusion also produced a significantly greater and reversible increase in blood pressure in $\mathrm{SR} / \mathrm{Jr}$ and Sprague-Dawley rats on the $8.0 \% \mathrm{NaCl}$ diet, compared with the corresponding strains of rats on the $0.3 \% \mathrm{NaCl}$ chow (Table I). In contrast, L-NMMA infusion produced proportionate increases in MAP in SS/Jr rats on both the low- and high-salt chow (Fig. 4). Finally, provision of L-arginine and its precursor, L-citrulline, but not D-arginine, rapidly normalized blood pressure in hypertensive $\mathrm{SS} / \mathrm{Jr}$ rats fed the high- $\mathrm{NaCl}$ diet for 2 wk (Table II) and, importantly, prevented the development of hypertension caused by the high-salt diet during observation for 2 wk (Tables III, IV, and VI). In addition, baseline mean urinary cGMP level was higher in normotensive $\mathrm{SS} / \mathrm{Jr}$

Table IV. Data from SS/Jr Rats after $6 \mathrm{~d}$ on $8 \% \mathrm{NaCl}$ Chow and Daily i.p. Injections of Either L-Citrulline or Vehicle

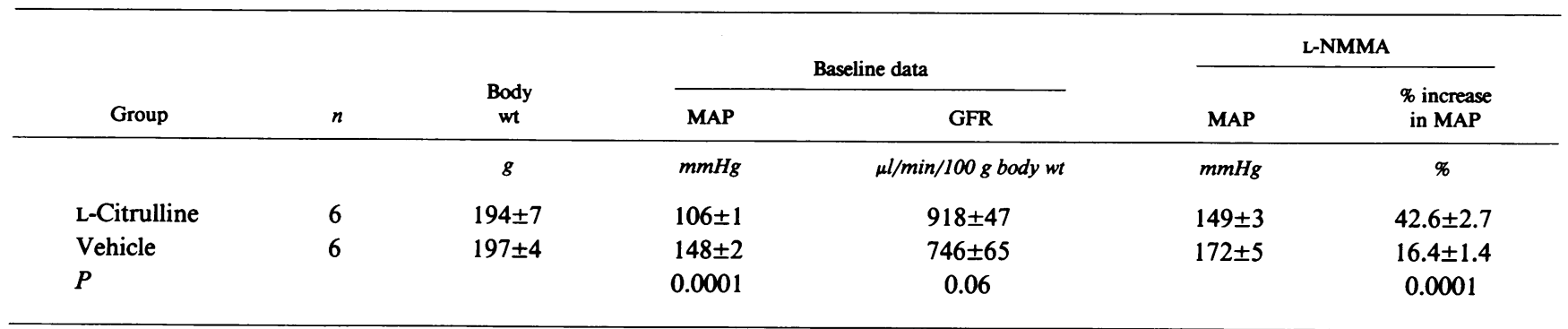


Table V. Effects of L-NMMA and L-Arginine on Spontaneously Hypertensive Rats after 2 wk on the 8\% NaCl Chow and Given i.p. Either L-Arginine or D-Arginine

\begin{tabular}{|c|c|c|c|c|c|c|c|c|}
\hline \multirow[b]{2}{*}{ Group } & \multirow[b]{2}{*}{$n$} & \multirow[b]{2}{*}{$\begin{array}{c}\text { Body } \\
\text { wt }\end{array}$} & \multicolumn{2}{|c|}{ Baseline Data } & \multicolumn{3}{|c|}{ L-NMMA } & \multirow[b]{2}{*}{$\frac{\text { L-Arginine }}{\text { MAP }}$} \\
\hline & & & MAP & seline Data & MAP & $\begin{array}{l}\text { Change } \\
\text { in MAP }\end{array}$ & GFR & \\
\hline & & $g$ & $\mathrm{mmHg}$ & $\mu l / \mathrm{min} / 100 \mathrm{~g}$ body $\mathrm{wt}$ & $\mathrm{mmHg}$ & $\%$ & $\mu l / m i n / 100 \mathrm{~g}$ body $w t$ & $m m H g$ \\
\hline L-Arginine & 8 & $155 \pm 6$ & $165 \pm 3$ & $923 \pm 84$ & $181 \pm 3$ & $+9.9 \pm 2.6$ & $1165 \pm 104$ & $166 \pm 2$ \\
\hline D-Arginine & 6 & $168 \pm 6$ & $160 \pm 3$ & $902 \pm 115$ & $180 \pm 3$ & $+13.0 \pm 3.5$ & $1016 \pm 147$ & $162 \pm 6$ \\
\hline
\end{tabular}

No statistically significant differences were found between the two groups.

rats treated for 2 wk with the L-arginine drink, compared to the hypertensive rats that received the D-arginine drink. Urinary cGMP decreased while blood pressure increased acutely with infusion of L-NMMA; urinary CGMP increased while blood pressure fell rapidly after stopping this infusion and administering a single intravenous bolus of L-arginine (Fig. 5). Tolins and associates (12) demonstrated a significant correlation between endothelium-dependent changes in blood pressure and urinary cyclic GMP in Sprague-Dawley rats treated with acetylcholine, which stimulates production of endothelium-derived relaxing factor. Thus, although direct measurements of nitric oxide were not performed in our study, indirect assays that included determination of changes in blood pressure and urinary CGMP, which are the functional results of NO production, and use of a competitive inhibitor of NO synthesis demonstrated an important role of dietary sodium chloride in augmenting NO activity in the SR/Jr strain. NO activity did not increase in the SS/Jr rats in response to increases in dietary sodium chloride and hypertension developed unless provided $\mathrm{L}$-arginine or L-citrulline, a precursor of $\mathrm{L}$-arginine production in endothelial cells (19).

With L-NMMA infusion, GFR fell despite an increase in blood pressure in the SR/Jr rats on the $8.0 \%$, but not the $0.3 \%$, $\mathrm{NaCl}$ diet. L-NMMA infusion did not change GFR in the SS/Jr rats on either diet and increased GFR in the Sprague-Dawley rats on the high-salt diet (Table I). These data suggested that unlike the age-matched Sprague-Dawley and SS/Jr rats, in the $\mathrm{SR} / \mathrm{Jr}$ rats during high $\mathrm{NaCl}$ intake $\mathrm{NO}$ was an important factor maintaining GFR, thus facilitating excretion of $\mathrm{NaCl}$ and

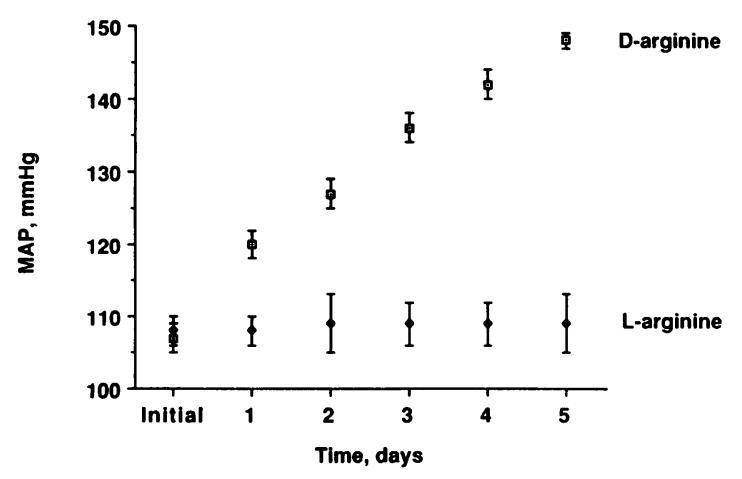

Figure 3. Effect of oral L-arginine on MAP of awake unrestrained $\mathrm{SS} / \mathrm{Jr}$ rats on the high-salt diet. MAP increased from $108 \pm 2$ to $148 \pm 1$ $\mathrm{mmHg}$ in the D-arginine group, but did not change (107 \pm 2 to $109 \pm 4$ $\mathrm{mmHg}$ ) in the $\mathrm{L}$-arginine group. Average blood pressures of the two groups differed $(P<0.005)$ by the second day of treatment. perhaps partially explaining their marked resistance to high dietary sodium chloride intake. Glomerular endothelial cells in culture have been shown to release NO which increased cGMP concentrations in cultured mesangial cells (20). In separate studies, renal vascular resistance of Sprague-Dawley rats increased with a decrease in NO (5). Thus, the different response of GFR to L-NMMA in the SR/Jr rats on the high-salt diet may have reflected an enhanced sensitivity of glomerular mesangial cells, which serve as one control of glomerular ultrafiltration (21), or renal vasculature to decreased NO activity.

Our data suggested an important role of NO in salt-sensitive hypertension in the SS/Jr rats. Unlike the SR/Jr and Sprague-Dawley rats, the high-salt diet did not enhance the effects of L-NMMA on blood pressure in the SS/Jr rats (Fig. 4 and Table I); we interpreted these data to suggest that NO production was not increased in these animals in response to the increase in dietary $\mathrm{NaCl}$. However, another potential explanation for this apparent lack of modulation of NO production was chronic hypertension, which has been shown to decrease endothelium-dependent relaxation of aortic rings obtained from several models of hypertension including the Dahl rat; this defect, which presumably was secondary to diminished production of endothelium-derived NO, corrected when hypertension was reversed (22). Dohi and associates (23) demonstrated a decrease in endothelium-dependent inhibition of norepinephrine-induced contractions in dissected mesenteric arteries of 16-20-wk-old normotensive Wistar-Kyoto rats, compared with arteries from rats $8 \mathrm{wk}$ of age; hypertension contributed to this inhibition in the 16-20-wk-old spontaneously hypertensive rats. These findings underscore the importance of examining NO activity in young rats that have been hypertensive for a short duration. Our SS/Jr rats were 5-7 wk old and had been fed the $8.0 \% \mathrm{NaCl}$ chow for only $2 \mathrm{wk}$, so that they were overtly hypertensive for a relatively short period of time. Intravenous boluses of $\mathrm{L}$-arginine, the substrate for NO synthesis $(1,2,4,7-9)$, acutely decreased blood pressure of hypertensive $\mathrm{SS} / \mathrm{Jr}$ rats to levels similar to the $\mathrm{SR} / \mathrm{Jr}$ rats (Tables I and II). In contrast, L-arginine did not lower blood pressure in spontaneously hypertensive rats, which had blood pressure of elevation and duration comparable to the $\mathrm{SS} / \mathrm{Jr}$ rats (Table V). Thus, although the absence of augmented NO activity could have been secondary to the effects of hypertension itself, the resistance vessels of the hypertensive SS/Jr rats responded rapidly and appropriately to the addition of the substrate for endothelium-dependent relaxation and allowed blood pressure to return to normotensive levels. This vasodilatory effect of L-arginine occurred selectively in SS/Jr rats and not in spontaneously hypertensive rats. 
Table VI. Effects of L-NMMA and L-Arginine on Anesthetized SS/Jr Rats after 2 wk on $8 \%$ NaCl Chow and Oral L-Arginine or D-Arginine

\begin{tabular}{|c|c|c|c|c|c|c|c|c|}
\hline \multirow[b]{3}{*}{ Group } & \multirow[b]{3}{*}{$n$} & \multirow{3}{*}{$\begin{array}{l}\text { Body } \\
\text { wt }\end{array}$} & \multirow{2}{*}{\multicolumn{2}{|c|}{ Baseline data }} & \multicolumn{3}{|c|}{ L-NMMA } & \multirow{3}{*}{$\frac{\text { L-Arginine }}{\text { MAP }}$} \\
\hline & & & & & & & & \\
\hline & & & MAP & GFR & MAP & in MAP & GFR & \\
\hline & & $g$ & $m m H g$ & $\mu l / \min / 100 \mathrm{~g}$ body $w t$ & $m m H g$ & $\%$ & $\mu \mathrm{l} / \mathrm{min} / 100 \mathrm{~g}$ body $w t$ & $m m H g$ \\
\hline L-Arginine & 9 & $228 \pm 9$ & $117 \pm 2$ & $924 \pm 19$ & $169 \pm 2$ & $+43.9 \pm 1.0$ & $1018 \pm 42$ & $116 \pm 2$ \\
\hline D-Arginine & 7 & $222 \pm 15$ & $158 \pm 3$ & $1100 \pm 27$ & $185 \pm 4$ & $+17.1 \pm 2.2$ & $1126 \pm 27$ & $128 \pm 2^{*}$ \\
\hline$P$ & & & 0.0001 & 0.0001 & 0.003 & 0.0001 & & 0.04 \\
\hline
\end{tabular}

${ }^{*} P<0.05$ compared with baseline MAP of the D-arginine group.

More importantly, our data also showed the efficacy of Larginine in the prevention of hypertension in SS/Jr rats but not in the spontaneously hypertensive strain of rat. Daily intraperitoneal injections of $\mathrm{L}$-arginine or $\mathrm{L}$-citrulline as well as oral $\mathrm{L}$-arginine prevented hypertension in SS/Jr rats (Figs. 1-3). Prevention of hypertension occurred in a dose-response fashion, with doses as low as $25 \mathrm{mg} / \mathrm{kg}$ per d achieving some effect. In contrast, parenteral doses of L-arginine, $250 \mathrm{mg} / \mathrm{kg}$ per $\mathrm{d}$, did not prevent development of hypertension in spontaneously hypertensive rats (Table V). D-Arginine had no effect on blood pressure regulation in the SS/Jr rats and L-arginine did not lower blood pressure in the SR/Jr rats. In SS/Jr rats, L-arginine also increased urinary cGMP (Fig. 5), another index of NO activity (12). In our hands, after 4 wk on the high-salt diet, $\mathrm{SS} / \mathrm{Jr}$ rats $(n=16)$ on oral L-arginine were normotensive with blood pressures similar to $\mathrm{SR} / \mathrm{Jr}$ rats $(n=8)$ on the same diet (SS/Jr rats, $115 \pm 2 \mathrm{mmHg}$ vs. SR/Jr rats, $115 \pm 2 \mathrm{mmHg}$ ); 10 of $16 \mathrm{SS} / \mathrm{Jr}$ rats on the high-salt diet alone died during the period of observation (unpublished observation). While on the highsalt diet, SR/Jr and Sprague-Dawley rats but not SS/Jr rats demonstrated an augmented blood pressure response to $\mathrm{L}-$ NMMA; provision of the substrates for NO restored this augmented blood pressure response to the inhibitor of NO production in SS/Jr rats (Fig. 4). Recognizing there are potential differences in the physiological and biochemical characteristics between SS/Jr and SR/Jr rats, the data, taken together, support the hypothesis that one of the defects producing hypertension in the SS/Jr rats was a reduced NO production which could be corrected with L-arginine.

Table VII. Urinary cGMP Concentrations: Baseline, during Infusion of L-NMMA and after L-Arginine Bolus in Anesthetized SS/Jr Rats after 2 wk on $8 \% \mathrm{NaCl}$ Chow and Oral L-Arginine or D-Arginine

\begin{tabular}{lccc}
\hline Group & $\begin{array}{c}\text { Urine [cGMP] } \\
\text { baseline }\end{array}$ & $\begin{array}{c}\text { [CGMP] during } \\
\text { L-NMMA infusion }\end{array}$ & $\begin{array}{c}\text { [CGMP] after } \\
\text { L-arginine bolus }\end{array}$ \\
\hline \multicolumn{4}{c}{ pmol/ml GFR per 100g body $w t$} \\
L-Arginine & $15.0 \pm 1.9$ & $7.4 \pm 1.9^{*}$ & \\
D-Arginine & $9.3 \pm 1.1$ & $4.7 \pm 1.0^{*}$ & $26.2 \pm 4.2$ \\
$P$ & 0.03 & & $12.7 \pm 2.9$ \\
& & & 0.03
\end{tabular}

* $P<0.05$ compared with cGMP values at baseline and after the L-arginine bolus in the same group.
NO synthase has recently been purified by Bredt and Snyder (24). This 150-kD enzyme requires NADPH, calmodulin, and calcium to convert L-arginine to L-citrulline and NO (24). Immunohistochemical studies have localized this NO synthase in the rat to various neurons throughout the brain and to the endothelium of blood vessels. Immunoprecipitation of this protein from solution or addition of benzylnitroarginine, another guanidino nitrogen-substituted arginine molecule, inhibits production of NO (25). Thus, along with several essential cofactors, a single gene product, NO synthase, may be responsible for NO generation by the endothelium.

We conclude that the salt-resistant Dahl/Rapp rats responded to an increase in dietary $\mathrm{NaCl}$ by augmenting $\mathrm{NO}$ production which served to maintain a constant blood pressure despite a high salt intake. Salt-sensitive Dahl/Rapp rats developed hypertension on the high-salt diet unless provided with exogenous L-arginine, which prevented the hypertensive response. The antihypertensive effect of $L$-arginine was not nonselective because it did not prevent the increase in blood pressure in the spontaneously hypertensive rat, nor did L-arginine lower established hypertension in these animals. While an abnormality linked to the renin gene locus (26) and renal impairment of salt excretion (27) may also play a role in development of hypertension in these rats perhaps by augmenting salt retention while on a high-salt diet, our data indicate that either L-arginine availability or the activity of NO synthase is abnormal in the salt-sensitive rats. We would suggest that the gene encoding

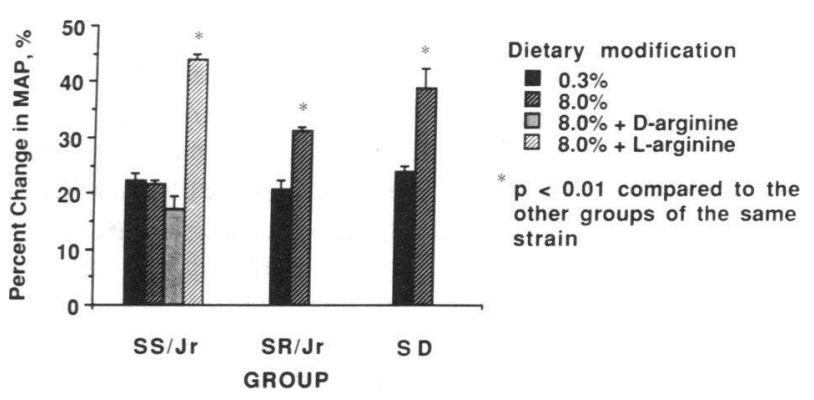

Figure 4. Results of L-NMMA infusion on MAP in SS/Jr, SR/Jr, and Sprague-Dawley (SD) rats. Dietary sodium chloride $(0.3$ or $8.0 \%)$ intake is shown in the legend; two additional groups of SS/Jr rats received oral D-arginine or L-arginine plus the high-salt diet. An increase in dietary sodium chloride increased $(P<0.01)$ the blood pressure response to L-NMMA in the SR/Jr and SD rats, but did not change the response in SS/Jr rats unless they had also received L-arginine. 

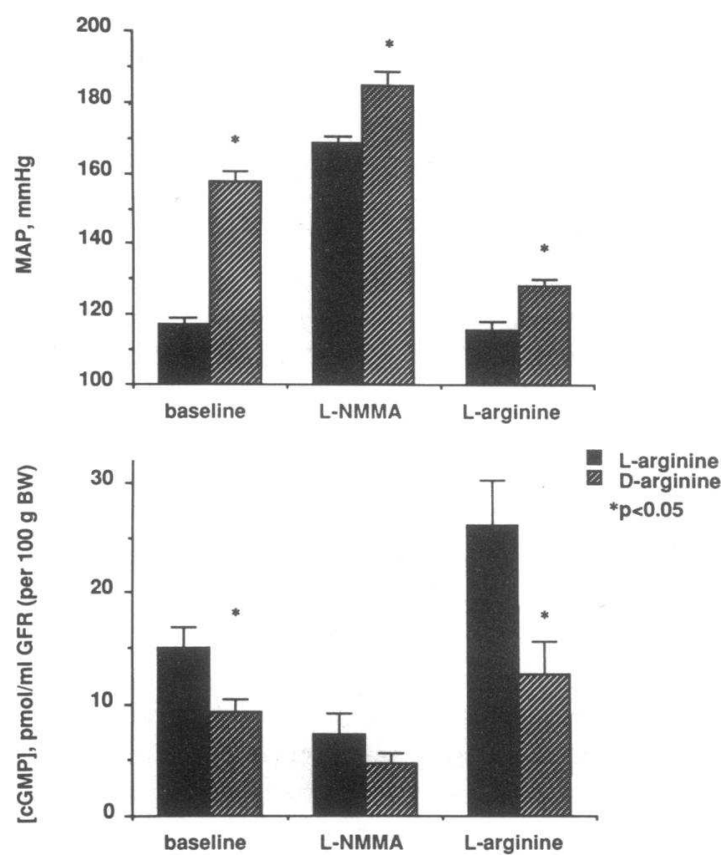

Figure 5. Effects of infusion of L-NMMA followed by L-arginine on blood pressure and urinary CGMP levels in SS/Jr rats on the $8.0 \%$ $\mathrm{NaCl}$ diet and receiving either $\mathrm{L}$-arginine or $\mathrm{D}$-arginine in their drink for the previous $2 \mathrm{wk}$. At baseline, blood pressure was lower and urinary CGMP higher in those rats treated with L-arginine. During infusion of L-NMMA, blood pressure increased and urinary cGMP fell acutely in both groups. Mean urinary cGMP during L-NMMA infusion was less $(P<0.05)$ than those values obtained both during baseline and recovery periods. After stopping this infusion and administering a single intravenous bolus of L-arginine, blood pressure rapidly fell and cGMP increased in both groups.

the endothelial form of NO synthase may be a candidate gene involved in the development of hypertension in the Dahl/Rapp salt-sensitive rat. However, as suggested by John P. Rapp (28), cross-breeding studies to show that this gene cosegregates with the hypertensive phenotype will be necessary to confirm this hypothesis. As hypertension persists, the effects of NO on vascular smooth muscle would be impaired further $(22,23)$, aggravating the hypertension and thus producing a positive feedback loop. The other possibility, that there is a defect in L-arginine handling or production in SS/Jr rats, seems less likely because oral L-arginine and intraperitoneal L-citrulline, an amino acid precursor for L-arginine in endothelial cells in culture (19) and in the kidney, protected SS/Jr rats from hypertension, suggesting the absorptive pathway for $\mathrm{L}$-arginine in the digestive tract and L-arginine production were intact. Recently, Sessa et al. (29) showed that biosynthesis of endothelium-derived relaxing factor by bovine aortic endothelial cells in culture was limited by the availability of intracellular L-arginine. Our study is the first in vivo demonstration that increased substrate availability can overcome a functional defect in NO production. To the extent that these results are applicable to humans, two recent reports confirmed a defect in acetylcholine-stimulated endothelium-dependent relaxation in the brachial arteries of patients with essential hypertension, compared with normotensive controls $(30,31)$. Endothelium-independent arterial relaxation from infusion of sodium nitroprusside was not altered in these patients $(30,31)$. Thus, abnormal NO synthase function may be a major factor producing essential hypertension, especially the salt-sensitive variety, by impairing endothelium-dependent arteriolar relaxation. It remains to be seen if a defect in NO synthase is involved in the development of arteriolar hypertension in defined subsets of human essential hypertension.

\section{Acknowledgments}

The authors thank Dr. David G. Warnock and Beverly B. Booker for their support and helpful suggestions, the Media Service of the Veterans Administration for the illustrations, and Ms. Elaine Morse for secretarial assistance.

This work was supported by a George M. O'Brien Kidney and Urological Research Centers Program (National Institutes of Health P50DK-39258) and by the Research Service of the Veterans Administration.

\section{References}

1. Brenner, B. M., J. L. Troy, and B. J. Ballerman. 1989. Endothelium-dependent vascular responses. Mediators and mechanisms. J. Clin. Invest. 84:13731378.

2. Vane, J. R., E. E. Änggård, and R. M. Botting. 1990. Regulatory functions of the vascular endothelium. N. Engl. J. Med. 323:27-36.

3. Palmer, R. M. J., A. G. Ferrige, and S. Moncada. 1987. Nitric oxide release accounts for the biological activity of endothelium-derived relaxing factor. $\mathrm{Na}$ ture (Lond.). 327:524-526.

4. Ignarro, L. J. 1990. Biosynthesis and metabolism of endothelium-derived nitric oxide. Annu. Rev. Pharmacol. Toxicol. 30:535-560.

5. Gardiner, S. M., A. M. Compton, T. Bennett, R. M. J. Palmer, and S. Moncada. 1990. Control of regional blood flow by endothelium-derived nitric oxide. Hypertension (Dallas). 15:486-492.

6. Arnold, W. P., C. K. Mittal, S. Katsuki, and F. Murad. 1977. Nitric oxide activates guanylate cyclase and increases guanosine $3^{\prime}: 5^{\prime}$-cyclic monophosphate levels in various tissue preparations. Proc. Natl. Acad. Sci. USA. 74:3203-3207.

7. Sakuma, I., D. J. Stuehr, S. S. Gross, C. Nathan, and R. Levi. 1988. Identification of arginine as a precursor of endothelium-derived relaxing factor. Proc. Natl. Acad. Sci. USA. 85:8664-8667.

8. Palmer, R. M. J. D. S. Ashton, and S. Moncada 1988. Vascular endothelial cells synthesize nitric oxide from L-arginine. Nature (Lond.). 333:664-666.

9. Rees, D. D., R. M. J. Palmer, and S. Moncada. 1989. Role of endotheliumderived nitric oxide in the regulation of blood pressure. Proc. Natl. Acad. Sci. USA. 86:3375-3378.

10. Marletta, M. A. 1989. Nitric oxide: biosynthesis and biological significance. Trends Biochem. Sci. 14:488-492.

11. Vallance, P., J. Collier, and S. Moncada. 1989. Effects of endotheliumderived nitric oxide on peripheral arteriolar tone in man. Lancet. ii:997-1000.

12. Tolins, J. P., R. M. J. Palmer, S. Moncada, and L. Raij. 1990. Role of endothelium-derived relaxing factor in regulation of renal hemodynamic responses. Am. J. Physiol. 258:H655-H662.

13. Rapp, J. P. 1982. Dahl salt-susceptible and salt-resistant rats. Hypertension (Dallas). 4:753-763.

14. Rapp, J. P., and H. Dene. 1985. Development and characteristics of inbred strains of Dahl salt-sensitive and salt-resistant rats. Hypertension (Dallas). 7:340-349.

15. Sanders, P. W., B. B. Booker, J. B. Bishop, and H. C. Cheung. 1990 Mechanisms of intranephronal proteinaceous cast formation by low molecular weight proteins. J. Clin. Invest. 85:570-576.

16. Furchgott, R.F., and J. V.Zawadzki. 1980. The obligatory role of endothelial cells in the relaxation of arterial smooth muscle by acetylcholine. Nature (Lond.). 288:373-376

17. Gold, M. E., K. S. Wood, R. E. Byrns, J. Fukuto, and L. J. Ignarro. 1990. $N^{G}$-Methyl-L-arginine causes endothelium-dependent contraction and inhibition of cyclic GMP formation in artery and vein. Proc. Natl. Acad. Sci. USA. 87:4430 4434.

18. Palmer, R. M. J., D. D. Rees, D. S. Ashton, and S. Moncada. 1988 L-Arginine is the physiological precursor for the formation of the nitric oxide in endothelium-dependent relaxation. Biochem. Biophys. Res. Commun. 153:1251-1256.

19. Hecker, M., W. C. Sessa, H. J. Harris, E. E. Änggärd, and J. R. Vane. 1990 The metabolism of $\mathrm{L}$-arginine and its significance for the biosynthesis of endothelium-derived relaxing factor: cultured endothelial cells recycle L-citrulline to Larginine. Proc. Natl. Acad. Sci. USA. 87:8612-8616.

20. Marsden, P. A., T. A. Brock, and B. J. Ballermann. 1990. Glomerular 
endothelial cells respond to calcium-mobilizing agonists with release of EDRF. Am. J. Physiol. 258:F1295-F1303.

21. Mene, P., M. S. Simonson, and M. J. Dunn. 1989. Physiology of the mesangial cell. Physiol. Rev. 69:1347-1424.

22. Luscher, T. F., D. Diederich, F. R. Buhler, and P. M. Vanhoutte. 1990. Interactions between platelets and the vessel wall: role of endothelium-derived vasoactive substances. In Hypertension: Pathophysiology, Diagnosis, and Management. J. H. Laragh and B. M. Brenner, editors. Raven Press, New York. 637-648.

23. Dohi, Y., M. A. Thiel, F. R. Buhler, and T. F. Luscher. 1990. Activation of endothelial L-arginine pathway in resistance arteries: effect of age and hypertension. Hypertension (Dallas). 16:170-179.

24. Bredt, D. S., and S. H. Snyder. 1990. Isolation of nitric oxide synthetase, a calmodulin-requiring enzyme. Proc. Natl. Acad. Sci. USA. 87:682-685.

25. Bredt, D. S., P. M. Hwang, and S. H. Snyder. 1990. Localization of nitric oxide synthase indicating a neural role for nitric oxide. Nature (Lond.). 347:768770.
26. Rapp, J. P., S.-M. Wang, and H. Dene. 1989. A genetic polymorphism in the renin gene of Dahl rats cosegregates with blood pressure. Science (Wash. DC). 243:542-544.

27. Kirchner, K. A. 1990. Greater loop chloride uptake contributes to blunted pressure natriuresis in Dahl salt-sensitive rats. J. Am. Soc. Nephrol. 1:180-186.

28. Rapp, J. P. 1983. A paradigm for identification of primary genetic causes of hypertension in rats. Hypertension (Dallas). 5(Suppl. I):I-198-I-203.

29. Sessa, W. C., M. Hecker, J. A. Mitchell, and J. R. Vane. 1990. The metabolism of L-arginine and its significance for the biosynthesis of endothelium-derived relaxing factor: L-glutamine inhibits the generation of L-arginine by cultured endothelial cells. Proc. Natl. Acad. Sci. USA. 87:8607-8611.

30. Linder, L., W. Kiowski, F. R. Buhler, and T. F. Luscher. 1990. Indirect evidence for release of endothelium-derived relaxing factor in human forearm circulation in vivo. Circulation. 81:1762-1767.

31. Panza, J. A., A. A. Quyyumi, J. E. Brush, and S. E. Epstein. 1990. Abnormal endothelium-dependent vascular relaxation in patients with essential hypertension. N. Engl. J. Med. 323:22-27. 